\title{
Efektifitas Ekstrak Daun Allamanda Cathartica L. Dalam Membasmi
} Jentik Nyamuk

\author{
${ }^{1}$ Arfiani Nur \\ ${ }^{2}$ Ummy Yatul Jannah \\ ${ }^{3}$ Subakir Salnus
}

\begin{abstract}
${ }^{1}$ Jurusan Kimia, Fakultas Sains dan Teknologi,UIN Alauddin Makassar,Indonesia
${ }^{2}$ Prodi DIII Analis Kesehatan,STIKES Panrita Husada Bulukumba,Indonesia

${ }^{3}$ Prodi DIII Analis Kesehatan,STIKES Panrita Husada Bulukumba,Indonesia
\end{abstract}

\section{Alamat Koresponden :}

Arfiani Nur

Jurusan Kimia

UIN Alauddin Makassar

Hp: 085230970706

Email : arfianinur@gmail.com 


\begin{abstract}
ABSTRAK
Penularan vektor nyamuk menimbulkan tiga akibat yaitu; kesakitan, kecacatan dan kematian. Salah satu cara memutuskan rantai vektor ini, dengan menggunakan larvasida alami yaitu dengan menggunakan bahan tanaman. Manfaat tanaman Allamanda yang dapat digunakan sebagai larvasida alami karena mengandung beberapa senyawa kimia terutama alkaloid, flavonoid, saponin dan tanin yang dapat memberikan pengaruh terhadap mortalitas jentik nyamuk. Jentik nyamuk meliputi Aedes, Culex dan Anopheles. Penelitian ini yaitu untuk mengetahui keefektifan ekstrak daun Allamanda dalam membasmi jentik nyamuk. Jenis penelitian ini penelitian ini adalah observasi laboratorik yang bersifat deskriptif dan tipe penelitian post test-only non equivalent control group group yakni dengan menganalisa keefektifan ekstrak daun allamanda terhadap mortalitas jentik nyamuk, dengan menggunakan daun Allamanda cathartica L. yang di ekstraksi dengan metode maserasi kemudian dibagi menjadi konsentrasi 5\%, 15\%, 25\%, 35\%. Hasil yang diperoleh terdapat jentik nyamuk Aedes sp dan Culex sp yang mati pada setiap konsentrasi, semakin tinggi konsentrasi semakin banyak jentik nyamuk yang mati. Ekstrak daun Allamanda memiliki pengaruh terhadap mortalitas jentik nyamuk dengan konsentrasi tinggi lebih efektif dalam membunuh jentik nyamuk. Dimana konsentrasi ekstrak daun berbanding lurus dengan kematian yang dihasilkan.
\end{abstract}

\title{
Kata Kunci : Ekstrak Daun Allamanda, Mortalitas, Jentik Nyamuk
}

\begin{abstract}
ABSTRAC
Transmission of mosquito vectors causes three effects, namely; pain, disability and death. One way to break this vector chain, using natural larvicides, is to use plant material. The benefits of the Allamanda plant can be used as natural larvicides because they contain several chemical compounds, especially alkaloids, flavonoids, saponins and tannins which can have an effect on mosquito larvae mortality. Mosquito larvae include Aedes, Culex and Anopheles. This research is to find out the effectiveness of Allamanda leaf extract in eradicating mosquito larvae. The type of this research is descriptive laboratory observations and post test-only non equivalent control group research that is by analyzing the effectiveness of the allamanda leaf extract on the mortality of mosquito larvae, using the leaves of Allamanda cathartica L. extracted by maceration method then divided to a concentration of $5 \%, 15 \%, 25 \%, 35 \%$. The results obtained there were larvae of Aedes sp and Culex sp that died at each concentration, the higher the concentration the more mosquito larvae died. Allamanda leaf extract has an influence on mortality of mosquito larvae with high concentrations more effective in killing mosquito larvae. Where the concentration of leaf extract is directly proportional to the resulting death.
\end{abstract}

Keywords: Allamanda Leaf Extract, Mortality, Mosquito larvae 


\section{PENDAHULUAN}

Nyamuk berperan sebagai vektor dari penyakit malaria, filariasis, Demam berdarah dengue (DBD), demam chikungunya, Japanese B. enchephalitis, demam kuning (yellow fever) dan demam $O$ nyong-nyong (Pusarawati et al., 2017). Penyakit akibat penularan vektor nyamuk itu setidaknya menimbulkan morbilitas seperti penyakit malaria akibat penularan nyamuk Anopheles, mortalitas seperti penyakit demam berdarah akibat gigitan nyamuk Aedes aegypti serta disabilitas seperti penyakit kaki gajah atau Filariasis akibat gigitan nyamuk Culex sp (Mingkid, 2017). Selain berbahaya, biaya perawatan penyakit tersebut juga sangat tinggi mencapai Rp 2 triliun seperti disebutkan pada data Direktorat Jenderal Pengendalian Penyakit dan Penyetahan Lingkungan Kementerian Kesehatan pada tahun 2016 (Rudiana, 2017).

Penggunaan larvasida merupakan salah satu upaya dalam menghambat pertumbuhan vektor nyamuk. Larvasida yang sering digunakan di Indonesia adalah temephos (abate) (Yulidar and Dinata, 2016). Pemakaian temephos dalam jangka yang lama, dosis dan waktu yang tidak tepat, dapat mengakibatkan terjadinya resistensi pada larva (Adrianto dan Yuwono, 2018).

Pada konsentrasi tinggi dapat menimbulkan overstimulasi sistem syaraf dan pada pajanan yang sangat tinggi, temephos dapat menyebabkan paralise nafas dan kematian (Yulidar dan Dinata, 2016). Oleh karena itu, salah satu solusi alternatif yaitu menggunakan larvasida alami. Salah satu tanaman yang dapat digunakan sebagai larvasida alami adalah tanaman Allamanda, Allamanda cathartica $L$ (Gambar 1).

Tanaman Allamanda ini tergolong tumbuhan beracun yang dimanfaatkan Masyarakat Dayak untuk mengiritasi kulit musuh dan sebagai insektisida dalam membasmi jentik nyamuk (Ilmi, Dharmono dan Hayani I, 2015). Menurut penelitian sebelumnya daun Allamanda mengandung senyawa fitokimia, antara lain alkaloid, flavonoid, terpenoid, steroid, saponin, dan tanin. Senyawa-senyawa tersebut berpotensi sebagai antimikrobia dan larvasida (Faradillah N., Agustina dan Rijai, 2015).

Pada penelitian ini dilakukan variasi konsentrasi ekstrak etanol dari daun Allamanda dengan tujuan menentukan efektifitas ekstrak tersebut sehingga berfungsi sebagai larvasida. Penelitian ini diharapkan dapat menjadi rujukan dalam pembuatan larvasida.

\section{METODE}

Adapun desain penelitian yang digunakan adalah Obseravsi laboratorik dengan tipe penelitian post test-only non equivalent control group yakni dengan 
menganalisa keefektifan ekstrak daun allamanda terhadap mortalitas jentik nyamuk. Sampel yang digunakan adalah sebagian jentik nyamuk yang diambil dari tiga tempat perindukan yang berbeda (air bersih, air kotor dan air payau).

Daun Allamanda diambil dari beberapa pohon tanaman Allamanda yang telah diidentifikasi bahwa tanaman tersebut benar jenis Allamanda cathartica L. Daun Allamanda dibuat dalam bentuk simplisia kering kemudian diekstrak menggunakan etanol 99,8\% dengan metode maserasi dengan perbandingan antara simplisia dengan pelarut sebesar 1:10. Maserasi dilakukan selama 5 hari. Setelah itu disaring kemudian larutan dipekatkan sehingga diperoleh ekstrak kental. Setelah itu dibuat variasi konsentrasi ekstrak 5\%; 15\%; 25\%; dan $35 \%$ menggunakan aquadest.

Analisis mortalitas larva dilakukan dengan menambahkan masing-masing 23 ekor jentik/larva nyamuk pada tiap konsentrasi. Kontrol negatif menggunakan aquades. Kemudian diamati selama 24 jam.

\section{HASIL}

Berdasarkan data kematian jentik nyamuk pada tabel 1 . dapat dilihat bahwa pada konsentrasi 5\% tidak mempengaruhi mortalitas atau kematian jentik nyamuk. Pada konsentrasi 15\%, telah ada jentik nyamuk yang mati sebanyak 2 ekor setelah 24 jam penambahanekstrak daun. Untuk konsentrasi $25 \%$, didapatkan 12 ekor jentik yang mati. Dan untuk konsentrasi tertinggi yaitu konsentrasi 35\%, didapatkan hasil bahwa semua jentik nyamuk mati setelah 24 Jam penambahan ekstrak daun Allamanda.

Persentase kematian jentik nyamuk tertinggi setelah 24 jam penambahan ekstrak daun Allamanda yaitu pada sediaan dengan konsentrasi 35\% sebanyak 100\%, kemudian pada sediaan dengan konsentrasi $25 \%$ sebanyak 52\%, dan pada sediaan dengan konsentrasi $15 \%$ sebanyak $9 \%$. Untuk persentase kematian nyamuk terendah yaitu pada sediaan dengan konsentrasi $5 \%$ yaitu sebanyak $0 \%$ jentik yang mati. Jenis nyamuk yang mati diidentifikasi sebagai nyamuk Aedes $S p$ dan Culex $S p$ seperti pada Gambar 2.

\section{PEMBAHASAN}

Pada penelitian ini, jentik nyamuk yang digunakan adalah jentik nyamuk yang didapatkan dari beberapa penampungan air didalam rumah warga, dan juga jentik yang didapatkan dari selokan sekitar permukiman warga. Jentik nyamuk yang baru diambil hanya dapat diidentifikasi dengan melihat ciri-ciri siphon, namun belum bisa dipastikan secara real bahwa itu jentik Culex atau Aedes.

Penambahan jentik nyamuk ke dalam sediaan dicatat waktunya, dan dibiarkan selama 24 jam. Hal ini juga diberlakukan pada sediaan 0\% ekstrak daun Allamanda atau kontrol negatif. Setelah 24 jam, diamati kembali keadaan jentik pada ke-5 sediaan 
dengan memindahkan sediaan dari erlenmeyer ke cawan petri kecil. Tujuan dari pemindahan sediaan ke cawan petri adalah agar dapat diketahui dengan jelas keadaan jentik.

Pada sediaan konsentrasi tertinggi yaitu konsentrasi 35\% didapatkan semua jentik nyamuk tenggelam dan tak merespon dengan sentuhan atau rangsangan (mati). Kemudian pada sediaan konsentrasi 25\% ada 8 ekor jentik yang mati, 1 ekor lambat merespon rangsangan dan kemudian mati, disusul dengan 3 ekor jentik yang bergerak aktif naik turun setelah ada rangsangan namun perlahan melambat dan tenggelam.

Untuk sediaan konsentrasi $15 \%$, hanya 2 ekor jentik yang mati. Dan pada sediaan konsentrasi rendah yaitu 5\%, tidak didapatkan jentik nyamuk yang mati. Sama halnya dengan sediaan konsentrasi $0 \%$ atau kontrol negatif yang hanya berisi aquadest, tidak didapati jentik nyamuk yang mati ataupun lambat merespon terhadap rangsangan.

Penambahan jentik nyamuk pada ke lima konsentrasi sediaan tersebut, di lakukan sebanyak tiga kali dan hasil yang didapatkan tetap sama. Dimana pada konsentrasi tertinggi lebih banyak jentik yang mati daripada konsentrasi yang rendah.

Gejala kematian jentik nyamuk ini sejalan dengan Hamidah (2001) tentang gejala awal yang teramati pada larva saat mengalami kontak dengan insektisida biasanya menimbulkan empat tahap gejala yaitu; eksitasi, konvulsi (kekejangan), paralisis (kelumpuhan) dan kematian. Pada tahap eksitasi, larva memperlihatkan kegelisahan (anxiety) dengan cara membersihkan badan seperti antena atau bagian tubuh lain dengan mulut, menggulung badannya dan melakukan gerakan teleskopik, yaitu gerakan turun naik yang sangat cepat pada permukaan air (Kaihena, Lalihatu and Nindatu, 2012).

Mortalitas larva nyamuk dapat ditandai dengan; larva tidak bergerak ketika disentuh, tubuh larva berwarna putih atau kuning pucat, bentuk tubuh memanjang dan kaku dan sebagian kepala terlepas atau seluruh tubuhnya hancur dan terapung diatas permukaan air dalam keadaan memanjang (Kaihena, Lalihatu and Nindatu, 2012).

Adapun faktor-faktor yang kemungkinan dapat mempengaruhi hasil pengujian efektifitas ekstrak daun Allamanda ini adalah faktor kimianya. Faktor kimia diantaranya faktor internal yaitu kandungan bahan kimia daun serta faktor eksternal yaitu metode ekstraksi yang digunakan (Aradilla AS, 2009).

Untuk faktor eksternalnya, metode ekstraksi yang digunakan dalam penelitian ini yaitu metode maserasi, namun saat pemekatan hasil ekstrak peneliti tidak menggunakan alat rotavapor sebagaimana 
penelitian-penelitian sebelumnya. Peneliti hanya menggunakan alat destilasi sederhana untuk menguapkan pelarut etanol dari ekstrak daun. Sehingga memungkinkan senyawa-senyawa yang terekstrak akan ikut menguap karena proses pemanasan yang lama.

Pelarut etanol dipilih berdasarkan penelitian terdahulu oleh Prabhadevi dkk (2012), Arundhina dkk (2014), yang mana pelarut etanol dapat melarutkan senyawa fitokimia tertentu di dalam daun allamanda dan setelah diuji menggunakan GC-MS ternyata beberapa senyawa di dalamnya diduga merupakan senyawa yang memiliki aktivitas sebagai antijamur, antikhamir, bahkan spesifik sebagai anticandida.

Selain itu etanol, juga dipilih karena menurut Harborne (1987) dan Voight (1994), etanol memiliki sifat yang mampu melarutkan hampir semua zat, baik yang bersifat polar, semi polar, dan non-polar juga menurut Ramadhan dan Phaza (2010), etanol merupakan pelarut yang tidak beracun dan berbahaya (Arundhina, Soegihardjo dan Sidharta, 2014).

Untuk faktor internalnya terdapat beberapa senyawa fitokimia yang terkandung didalam daun Allamanda, diantaranya adalah alkaloid, flavonoid, terpenoid, saponin, dan tanin (Arundhina, Soegihardjo dan Sidharta, 2014). Alkaloid yang berlebihan diduga akan menghambat kerjanya enzim asetilkolinesterase (AchE)

yang mengakibatkan terjadinya penumpukan asetilkolin sehingga menyebabkan kekacauan pada sistem penghantaran implus ke sel-sel otot. Hal ini menyebabkan pesan-pesan berikutnya tidak dapat diteruskan, larva mengalami kekejangan secara terus-menerus dan akhirnya terjadi kelumpuhan dan kondisi ini berlanjut terus sehingga menyebabkan kematian (Kaihena, Lalihatu and Nindatu, 2012).

Flavonoid menyerang beberapa organ saraf pada beberapa organ vital serangga, sehingga timbul suatu pelemahan saraf, seperti pernafasan dan timbul kematian. Flavonoid bekerja sebagai inhibitor pernafasan. Inhibitor merupakan zat yang menghambat atau menurunkan laju reaksi kimia, flavonoid juga mengganggu mekanisme energi didalam mitokondria dengan menghambat sistem pengangkutan elektron (Muta'ali and Purwani, 2015).

Saponin yang dapat menghambat kerja enzim pencernaan yang menyebabkan penurunan kerja alat pencernaan dan penggunaan protein Penyerapan saponin ke dalam usus larva dapat menghambat kerja enzim pencernaan serta mengakibatkan kerusakan sel-sel pada saluran pencernaan larva. Kerusakan dimulai dengan membengkaknya usus tengah hingga menyentuh dinding tubuh sehingga menyebabkan membrane peritrofik aseluler terlepas dari sel-sel usus tengah. Dan 
akhirnya sel-sel akan terpisah sehingga menyebabkan kematian pada larva (Kaihena, Lalihatu and Nindatu, 2012).

Tannin adalah senyawa polifenol yang dapat membentuk senyawa kompleks dengan protein (Muta'ali and Purwani, 2015). Tannin dapat menurunkan kemampuan mencerna makanan pada serangga dengan cara menurunkan aktivitas enzim percernaan (Safirah, Widodo and Budiyanto, 2016).

Jentik nyamuk yang telah mati, kemudian diidentifikasi dengan menggunakan mikroskop. Caranya, memipet jentik kemudian diletakkan diatas objek glas dan ditutupi dengan cover glas, lalu diamati dibawah mikrokop dengan menggunakan pembesaran objektif $4 \mathrm{x}$ dan $10 x$.

Hasil identifikasi jentik nyamuk yang mati didominasi oleh jentik nyamuk Culex $s p$. dan jentik nyamuk Aedes sp. Dari hasil hitungan jentik nyamuk yang mati berdasarkan jenis jentiknya didapati hasil bahwa kebanyakan jentik nyamuk yang mati adalah jentik Culex sp. yang berasal dari selokan diarea dekat permukiman warga.

Dari hasil penelitian diatas, kematian jentik nyamuk terbanyak pada sediaan dengan konsentrasi yang tinggi, yang disebabkan karena semakin tinggi konsentrasi maka peningkatan efek racun juga semakin tinggi. Dengan kata lain, semakin tinggi konsentrasi maka akan semakin tiggi mortalitas jentik nyamuk dan begitupun sebaliknya. Hal ini sesuai dengan Purba (2007) yang menyatakan bahwa peningkatan konsentrasi berbanding lurus dengan peningkatan bahan racun tersebut, sehingga daya bunuh semakin tinggi.

Dengan beberapa uraian diatas, maka hasil penelitian ini sejalan dengan teori dr. Setiawan Dalimartha bahwa getah tanaman Allamanda dapat digunakan untuk mematikan jentik nyamuk, dan teori ini juga didukung oleh penelitian dari Arundhina dkk, mengenai senyawa fitokima yang terkandung didalam daun Allamanda sehingga daun Allamanda berpotensi dalam membunuh jentik nyamuk.

\section{KESIMPULAN DAN SARAN}

Berdasarkan penelitian yang telah dilakukan maka ditarik kesimpulan bahwa ekstrak daun Allamanda dapat mempengaruhi mortalitas jentik nyamuk dimana konsentrasi tertinggi yaitu $35 \%$ sangat efektif dalam membunuh jentik nyamuk. Semakin tinggi konsetrasinya, maka semakin tinggi pula persentase kematian jentik nyamuk dalam waktu 24 jam.

Penelitian selanjutnya dapat dikhususkan pada jentik nyamuk Culex $s p$. Bagi masyarakat diharapkan dapat memanfaatkan daun Allamanda sebagai insektisida alami untuk membunuh nyamuk pada tempat perindukannya untuk 
mengurangi penyebaran penyakit yang ditularkan oleh nyamuk terutama pada penyakit Demam Berdarah Dengue dan Filaria.

\section{DAFTAR PUSTAKA}

Adrianto, H. and Yuwono, N. (2018) Pengantar Blok Penyakit Tropis Dari Zaman Kuno Hingga Abad 21 Terkini. I. Jawa Timur: PUSTAKA ABADI.

Arundhina, E., Soegihardjo, C. J. and Sidharta, B. B. R. (2014) 'Aktivitas Ekstrak Etanol Daun Alamanda (Allamanda Cathartica L.) Sebagai Antijamur Terhadap Candida Albicans Dan Pityrosporum Ovale Secara In Vitro'.

Dahlan, M. S., 2016. Besar Sampel Dalam Penelitian Kedokteran Dan Kesehatan. IV.Jakarta: Epidemiologi Indonesia.

Faradillah N., A., Agustina, R. and Rijai, L. (2015) 'Aktivitas Sediaan Gel Antiseptik Berbahan Aktif Fraksi NButanol Daun Alamanda (Allamanda Cathartica L.) Anintia', pp. 24-25.Diakses pada tanggal 8 Januari 2019, pukul 13:40.

Ilmi, J., Dharmono and Hayani I, N. (2015) 'Inventarisasi Dan Pemanfaatan Tumbuhan Beracun Oleh Masyarakat Dayak Bakumpai Di Desa Simpang Arja Kecamatan Rantau Badauh Kabupaten Barito Kuala', XIII, pp. 93-114. Diakses pada tanggal 8 Januari 2019, pukul 13:27.

Kaihena, M., Lalihatu, V. and Nindatu, M. (2012) 'Efektivitas Ekstrak Etanol Daun Sirih (Piper Betle L.) Terhadap Mortalitas Larva Nyamuk Anopheles Sp Dan Culex', Molucca Medica, 4(1), pp. 14-16.

Mingkid, G. S. (2017) 'nyamukberkembang-saat-cuaca-panas-iniyang-harus-diperhatikan', detiikNews. Available at: nyamuk- berkembang-saat-cuaca-panas-iniyang-harus-diperhatikan.html. Diakses pada tanggal 7 Januari 2019, pukul : 20:02.

Muta'ali, R. and Purwani, K. I. (2015) 'Pengaruh Ekstrak Daun Beluntas ( Pluchea indica ) terhadap Mortalitas dan Perkembangan Larva Spodoptera litura F.', SAINS DAN SENI ITS, 4(2), pp. 2-3. Diakses pada tanggal 8 Januari 2019, pukul 15:25.

Pusarawati, S. et al. (2017) Atlas Parasitologi Kedokteran. 2017th edn. Edited by S. H. B. Santoso et al. Surabaya.

RUDIANA, P. A. (2017) 'Menteri Kesehatan_ Kerugian Gara-gara Nyamuk Tembus Rp 2 Triliun Nasional Tempo', TEMPO.CO, August. Available at: Menteri Kesehatan_ Kerugian Gara-gara Nyamuk Tembus Rp 2 Triliun Nasional Tempo.co.html. Diakses pada tanggal 7 Januari 2019, pukul : 19:43

Safirah, R., Widodo, N. and Budiyanto, M. A. K. (2016) 'Uji Efektifitas Insektisida Nabati Buah Crescentia Cujete Dan Bunga Syzygium Aromaticum Terhadap Mortalitas Spodoptera Litura Secara In Vitro Sebagai Sumber Belajar Biologi, Pendidikan Biologi Indonesia, 2(3), pp. 273-278. Diakses pada tanggal 30 Desember 2018, pukul 23:20.

Yulidar and Dinata, A. (2016) Rahasia Daya Tahan Hidup Nyamuk Demam Berdarah; Cara cerdas mengenal Aedes aegypti dan Kiat sukses Pengendalian vektor DBD. 1st edn. Edited by U. P. Hastanto and C. M. Sartono. Yogyakarta: deepublish. 


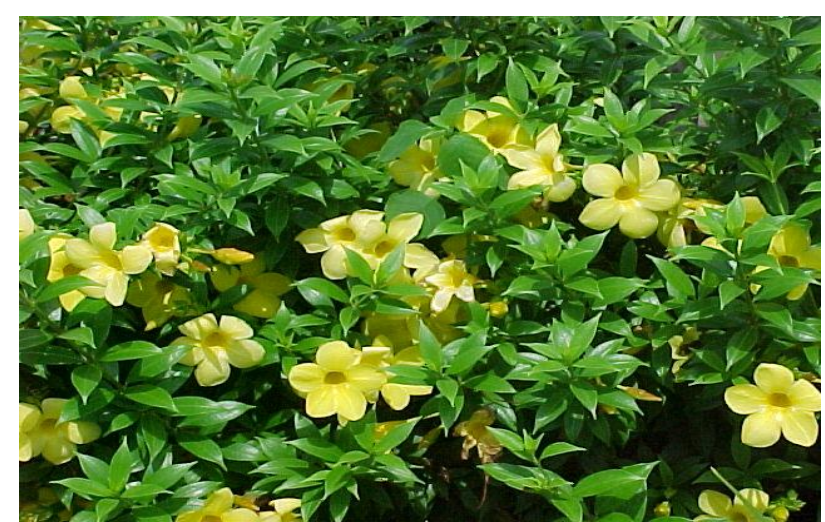

Gambar 1 Tanaman Allamanda Cathartica L

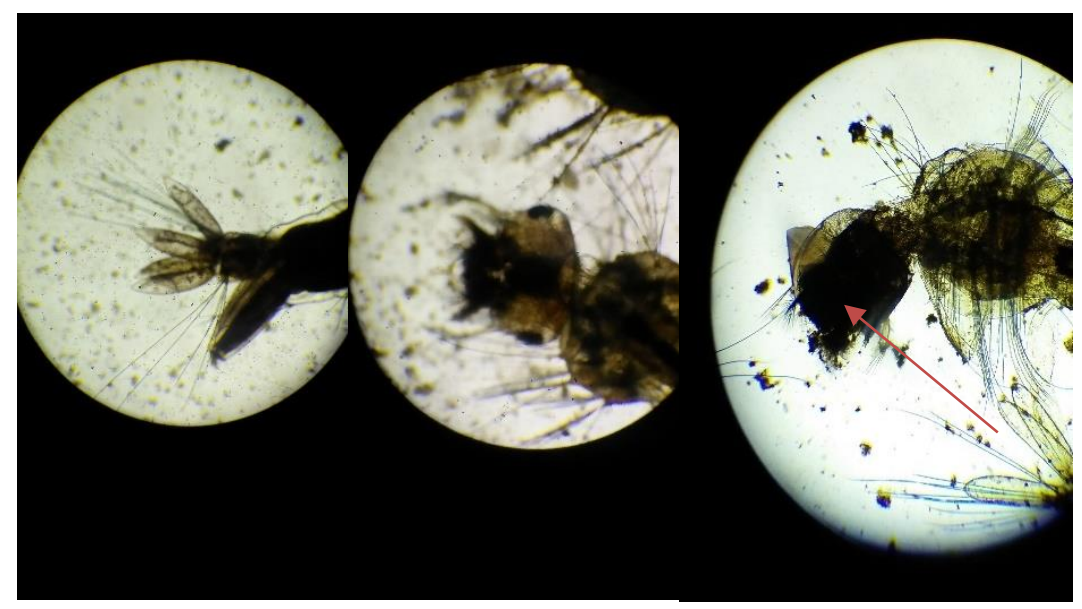

(a) Jentik nyamuk Aedes $S p$.

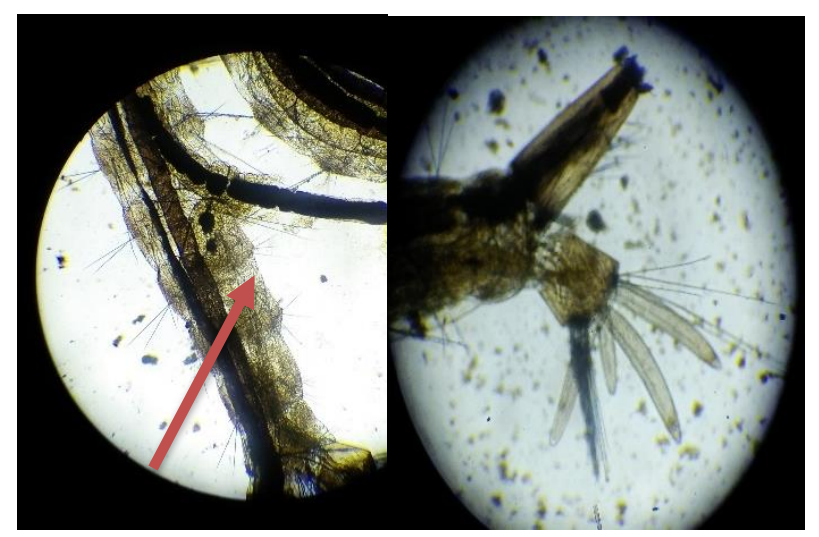

(b) Jentik nyamuk Culex $S p$.

Gambar 2. Identifikasi jentik nyamuk yang mati 
Tabel 1. Data Kematian Jentik Nyamuk bedasarkan perbedaan Konsentrasi Ekstrak daun Allamanda setelah 24 Jam

\begin{tabular}{|c|c|c|c|c|c|}
\hline \multirow{4}{*}{$\begin{array}{c}\text { Konsentrasi } \\
\text { Ekstrak Daun } \\
\text { Allamanda }\end{array}$} & \multirow{3}{*}{\multicolumn{2}{|c|}{$\begin{array}{c}\text { Keadaan Jentik } \\
\text { Nyamuk setelah } 24 \\
\text { Jam }\end{array}$}} & \multirow{2}{*}{\multicolumn{2}{|c|}{$\begin{array}{c}\text { Spesies Jentik yang } \\
\text { mati }\end{array}$}} & \multirow{4}{*}{$\begin{array}{c}\text { Persentase } \\
\text { Kematian } \\
(\%)\end{array}$} \\
\hline & & & & & \\
\hline & & & \multirow[b]{2}{*}{ Aedes } & & \\
\hline & Mati & Hidup & & Culex & \\
\hline $0 \%$ & 0 & 23 & 0 & 0 & $0 \%$ \\
\hline $5 \%$ & 0 & 23 & 0 & 0 & $0 \%$ \\
\hline $15 \%$ & 2 & 21 & 2 & 0 & $9 \%$ \\
\hline $25 \%$ & 12 & 11 & 5 & 7 & $52 \%$ \\
\hline $35 \%$ & 23 & 0 & 9 & 14 & $100 \%$ \\
\hline
\end{tabular}

